ANGGELIA WILLIA, PRADIPTA ANNURWANDA, RIZKI NURHANA FRIANTINI

Proses Pemecahan Masalah Matematika Ditinjau dari Gaya Belajar Siswa

\title{
Proses Pemecahan Masalah Matematika Ditinjau Dari Gaya Belajar Siswa
}

\author{
Anggelia Willia*1, Pradipta Annurwanda ${ }^{2}$, Rizki Nurhana Friantini ${ }^{3}$ \\ ${ }_{1,2,3}$ Program Studi Pendidikan Matematika, STKIP Pamane Talino \\ *anggeliawillia55@gmail.com
}

\begin{abstract}
ABSTRAK
Tujuan penelitian ini adalah untuk mengetahui gambaran proses pemecahan masalah pada setiap jenis gaya belajar siswa kelas X MIPA B SMA Negeri 1 Ngabang Tahun Ajaran 2019/2020 Kabupaten Landak. Penelitian ini merupakan penelitian kualitatif. Subjek dalam penelitian ini adalah 6 (enam) siswa kelas X MIPA B SMA Negeri 1 Ngabang. Pemilihan subjek penelitian menggunakan teknik purposive sampling. Teknik analisis data yang digunakan dalam penelitian ini adalah reduksi data, penyajian data, dan penarikan kesimpulan/verifikasi. Hasil penelitian ini menunjukkan bahwa 1) siswa dengan gaya belajar visual mampu memahami masalah dengan baik, mampu membuat rencana penyelesaian yang mudah dan sederhana sehingga dapat melakukan perhitungan dengan benar, dan dapat memeriksa kembali hasil jawaban dengan cara mengulang. Membaca soal dan hasil jawaban, 2) siswa dengan gaya belajar auditori mampu memahami masalah dengan baik, mampu membuat solusi yang mudah terhadap rencana, dapat melakukan perhitungan dengan benar, dan dapat memeriksa kembali hasil soal. Jawaban dengan membaca ulang soal dan hasil jawaban, 3) siswa dengan gaya belajar kinestetik sudah mampu memahami masalah tetapi belum mampu membuat rencana dan melaksanakan rencana sehingga sulit melakukan perhitungan dengan benar dan Pada tahap pengecekan ulang hasil kinestetik siswa dapat menguji kembali hasil jawaban dengan membaca ulang soal dan hasil jawaban.
\end{abstract}

Kata kunci: Gaya belajar, Pemecahan masalah Matematika, Polya

\begin{abstract}
The purpose of this study was to find out the description of the problem solving process in each type of learning style for grade X of MIPA B students in SMA Negeri 1 Ngabang in Academic Year 2019/2020, Landak Regency. This research is a qualitative research. The subjects in this study were 6 (six) students of grade X MIPA B of SMA Negeri 1 Ngabang. The selection of research subjects is based on a purposive sampling technique. Data analysis techniques used in this study are data reduction, data display, and conclusion drawing / verification. The results of this study indicate that 1) students with visual learning styles are able to understand problems well, are able to make easy and simple settlement plans so that they can do calculations correctly, and can re-examine the results of answers by re-reading the questions and the results of the answers, 2) students with the auditory learning style able to understand the problem well, able to make an easy solution to the plan, can do the calculations correctly, and can re-examine the results of the answers by re-reading the questions and the results of the answers, 3) students with kinesthetic learning styles are able to understand the problem but have not been able to make plans and carry out plans so that it is difficult to do the calculations correctly and at the stage of re-checking the results kinesthetic students can reexamine the results of the answers by rereading the questions and the results of the answers.
\end{abstract}

Key words: Learning style, Mathematical problem solving, Polya

Received: 2020-08-12

/ Accepted: 2020-10-08

/ Publised: 2020-11-01

\section{Pendahuluan}

Pemecahan masalah matematis merupakan salah satu tujuan penting dalam pembelajaran matematika bahkan proses pemecahan masalah matematis merupakan jantungnya matematika (Ulvah \& Afriansyah, 2016). Pemecahan masalah matematis dianggap sebagai inti pokok matematika karena berbagai macam kegiatan matematika adalah untuk memecahkan masalah (Winata \& Friantini, 2018b). Kepemilikan kemampuan pemecahan masalah membantu siswa meningkatkan kemampuan berpikir kritis dalam menghadapi situasi baru. Dengan demikian kemampuan pemecahan masalah matematis sangat penting dimiliki oleh siswa. Menurut Winata \& Friantini (2018a) pemecahan masalah merupakan salah satu kemampuan yang penting, baik pada pembelajaran atau pada kehidupan sehari-hari. Khususnya pada 
pembelajaran matematika, kemampuan pemecahan masalah sangat diperlukan ketika memecahkan masalah-masalah matematika. Menurut Ormrod (Agustina, 2014) pemecahan masalah memerlukan pengetahuan dan keterampilan yang sudah ada untuk menjawab pertanyaan yang belum terjawab atau situasi yang sulit. Masing-masing siswa berbeda dalam melakukan pemecahan masalah. Perbedaan tersebut salah satunya dikarenakan masing-masing siswa memiliki gaya belajar yang berbeda. Perbedaan gaya belajar menyebabkan perbedaan kemampuan siswa dalam mengolah dan memecahkan masalah. Oleh karena gaya belajar siswa yang berbeda, maka sangat penting bagi guru untuk menganalisis gaya belajar siswa sehingga diperoleh informasi-informasi yang dapat membantu guru untuk lebih peka dalam memahami perbedaan di dalam kelas dan dapat melaksanakan pembelajaran yang bermakna.

Menurut Deporter dan Hernacki (2012) gaya belajar seseorang adalah kombinasi dari bagaimana ia menyerap, dan kemudian mengatur serta mengolah informasi. Seorang anak akan mudah menguasai materi pelajaran dengan menggunakan cara belajar mereka masing-masing. Menurut Deporter dan Hernacki (2012) gaya belajar ada tiga, yaitu: visual, auditorial dan kinestetik. Orang visual belajar melalui apa yang mereka lihat, pelajar auditorial belajar melalui apa yang mereka dengar danpelajar kinestetik belajar lewat gerak dan sentuhan.Gaya belajar merupakan cara di mana individu memproses dan mengolah informasi dalam situasi belajar sehingga masing-masing gaya belajar mungkin mempunyai cara memproses dan mengolah informasi yang berbeda (Friantini \& Winata, 2018).

Menurut Branca (Nurfatanah dkk, 2018) kemampuan pemecahan masalah merupakan tujuan umum pembelajaran matematika, pemecahan masalah meliputi metode, prosedur, dan strategi yang merupakan proses inti dan utama dalam kurikulum matematika dan pemecahan masalah merupakan kemampuan dasar dalam belajar matematika.Adapun langkah-langkah kegiatan pemecahan masalah menurut Polya (Winata dkk, 2020) adalah sebagai berikut : 1) memahami masalah, siswa dapat memahami masalah atau soal; 2) merencanakan atau merancang strategi pemecahan masalah, menemukan hubungan antara yang diketahui dan ditanyakan dari masalah; 3) melaksanakan perhitungan, melakukan perhitungan sesuai dengan rencana yang sudah dibuat sebelumnya; dan 4) melihat kembali, memeriksa kebenaran hasil atau solusi. Menurut Polya (Hidayah, 2016) dalam memahami masalah siswa harus memahami masalah yang diberikan yaitu menentukan apa yang diketahui dan apa yang ditanyakan untuk menyelesaikan soal yang diberikan. Dalam merencanakan strategi pemecahan masalah siswa harus mampu menentukan pemisalan variabel, membuat model matematika, menentukan starategi atau metode yang akan digunakan dan menuliskan langkah-langkah yang akan digunakan dalam menyelesaikan soal. Dalam melaksanakan rencana siswa melakukan rencana yang telah ditetapkan pada tahap merencanakan pemecahan masalah dan dalam memeriksa kembali kebenaran siswa melakukan refleksi yaitu mengecek atau menguji solusi yang telah diperoleh.

Dari hasil observasi di SMAN 1 Ngabang khususnya di kelas X MIPA B mengalami beberapa kendala dalam menyelesaikan soal pemecahan masalah matematika dengan menggunakan langkah-langkah Polya yaitu memahami masalah, merencanakan atau merancang strategi pemecahan masalah, melaksanakan rencana (perhitungan) dan memeriksa kembali kebenaran hasil atau solusi. Dalam menyelesaikan soal tes pemecahan masalah siswa belum menuliskan data yang diketahui dan data yang ditanyakan dalam soal yang diberikan, artinya siswa belum bisa memahami masalah. Padahal memahami masalah termasuk bagian dari pemecahan masalah matematika menurut Polya. Selain itu siswa belum bisa memikirkan langkah apa yang dapat digunakan untuk memecahkan masalah yang dihadapinya sehingga dalam menyelesaikan 
ANGGELIA WILLIA, PRADIPTA ANNURWANDA, RIZKI NURHANA FRIANTINI

Proses Pemecahan Masalah Matematika Ditinjau dari Gaya Belajar Siswa

soal yang diberikan siswa membutuhkan waktu yang lama untuk bisa memahami soal dan menyelesaikan perhitungan.

Pemecahan masalah matematika dalam dunia pendidikan matematika harus diperhatikan oleh pendidik. Pendidik tentu harus mengetahui gaya belajar yang dimiliki oleh siswa sehingga dari gaya belajar yang dimiliki oleh siswa, pendidik dapat melihat tingkat kemampuan pemecahan masalah matematika berdasarkan gaya belajar yang dimiliki oleh siswa tersebut.Tujuandari penelitian ini untuk mengetahui deskripsi proses pemecahan masalah pada masing-masing tipe gaya belajar siswa kelas X MIPA B di SMA Negeri 1 Ngabang Tahun Ajaran 2019/2020 Kabupaten Landak.

\section{Metode Penelitian}

Penelitian ini merupakan penelitian kualitatif.Penelitian ini dilaksanakan di SMA Negeri 1 Ngabang yang terletak di Jalan Veteran Ngabang, Desa Hilir Tengah, Kecamatan Ngabang, Kabupaten Landak.Penelitian ini dilaksanakan pada semester ganjil Tahun Ajaran 2019/2020. Subjek penelitian yang menjadi sumber informasi mengenai proses pemecahan masalah matematika adalah 6 (enam) orang siswa kelas X MIPA B SMA Negeri 1 Ngabang.Penentuan subjek penelitian sebanyak 6 (enam) orang siswa tersebut berdasarkan pengambilan sampel secara purposive sampling dari siswa kelas X MIPA B.Menurut Sugiyono (2017) Purposive Sampling adalah teknik penentuan sampel dengan pertimbangan tertentu.Pemilihan subjek ini berdasarkan pertimbangan dengan memperhatikan kriteria sebagai berikut: 1) siswa memiliki gaya belajar visual, auditorial atau kinestetik yang diperoleh dari hasil angket gaya belajar; 2) hasil tes kemampuan pemecahan masalah matematika terlengkap saat mengerjakan soal tes pemecahan masalah; dan 3) sudah mendapatkan materi persamaan dan pertidaksamaan nilai mutlak linear satu variabel.

Menurut Sugiyono (2011) dalam penelitian kualitatif yang menjadi instrumen penelitian adalah peneliti itu sendiri.Dalam penelitian ini peneliti menggunakan instrumen bantu yang berupa angket, instrumen tes dan pedoman wawancara untuk mendapatkan data yang valid.Instrumen angket bertujuan untuk memperoleh data gaya belajar siswa.Instrumen tes kemampuan pemecahan masalah matematika bertujuan untuk mengetahui proses pemecahan masalah siswa dan instrumen wawancara bertujuan untuk mengetahuiproses pemecahan masalah matematika siswa ditinjau dari gaya belajar.Teknik pengumpulan data pada penelitian ini terdiri dari : 1) angket adalah teknik pengumpulan data yang dilakukan dengan cara memberi seperangkat pertanyaan atau pernyataan tertulis kepada responden untuk dijawabnya (Sugiyono, 2017); 2) tes adalah serentetan pertanyaan atau latihan serta alat lain yang digunakan untuk mengukur keterampilan, pengetahuan intelegensi, kemampuan atau bakat yang dimiliki oleh individu atau kelompok; dan 3) wawancara adalah sebuah dialog yang dilakukan oleh pewawancara untuk memperoleh informasi dari terwawancara (Arikunto, 2010).

Teknik analisis data yang digunakan dalam penelitian ini adalah analisis data model Miles dan Huberman. Menurut Sugiyono (2017) aktivitas dalam analisis data kualitatif dilakukan secara interaktif dan berlangsung secara terus menerus sampai tuntas, sehingga datanya sudah jenuh. Aktivitas dalam analisis data yaitu data reduction, data display, dan data conclusion drawing/verification. 


\section{Hasil dan Pembahasan}

Berdasarkan hasil analisis jawaban tes dan hasil wawancara yang dilakukan pada subjek untuk masing-masing gaya belajar siswa pada tahap pemecahan masalah yaitu memahami masalah, membuat rencana, melaksanakan rencana dan memeriksa kembali hasil adalah sebagai berikut.

\section{Proses pemecahan masalah siswa tipe visual}

Subjek visual 1 (SV1)

Tahap Memahami Masalah

Dalam memahami masalah dapat disimpulkan bahwa SV1 mampu memahami masalah dengan baik yaitu dengan cara menyebutkan apa yang diketahui dan ditanyakan dari soal yang diberikan. Hal tersebut terlihat pada gambar 1 berikut.
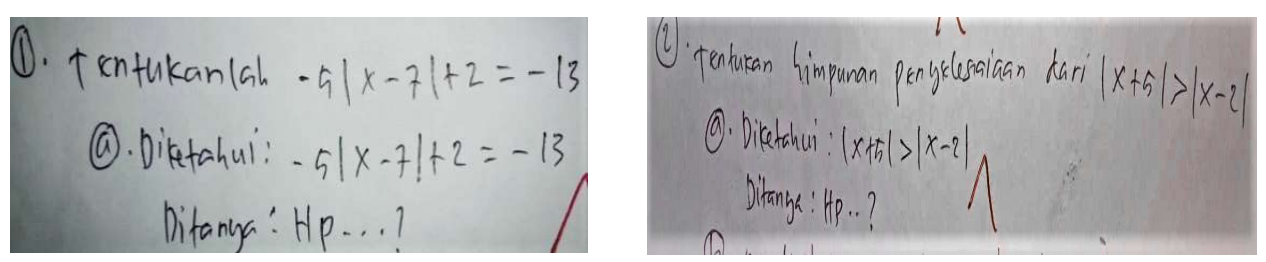

Gambar 1. Tahap memahami masalah SV1 soal nomor 1 dan 2

Tahap Membuat Rencana

Pada tahap ini SV1 juga mampu membuat rencana yang mudah dan sederhana untuk menyelesaikan soal nomor 1 dan soal nomor 2. Hal tersebut terlihat pada gambar 2 berikut.

\section{(b.) ubahlah $-4|x-7|+2=-13$ menjadi $|x-7|=a$}

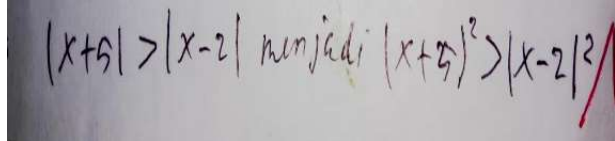

Gambar 2. Tahap membuat rencana SV1 soal nomor 1 dan 2

Tahap Melaksanakan Rencana

Pada tahap melaksanakan rencana SV1 mampu melakukan perhitungan dengan tepat sesuai dengan sifat yang ada pada nilai mutlak. Hal tersebut terlihat pada gambar 3 berikut.
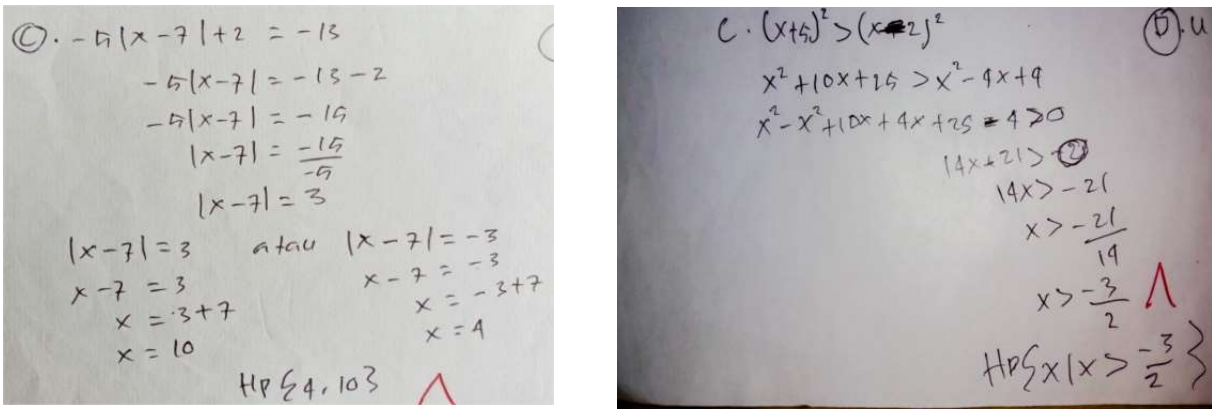

Gambar 3. Tahap melaksanakan rencana SV1 soal nomor 1 dan 2 
Tahap Memeriksa Kembali Hasil

Pada tahap memeriksa kembali hasil SV1 melakukan pengecekan kembali dengan cara memberikan pembuktian jawaban dan membaca kembali pertanyaan. Hal tersebut terlihat pada gambar 4 berikut.
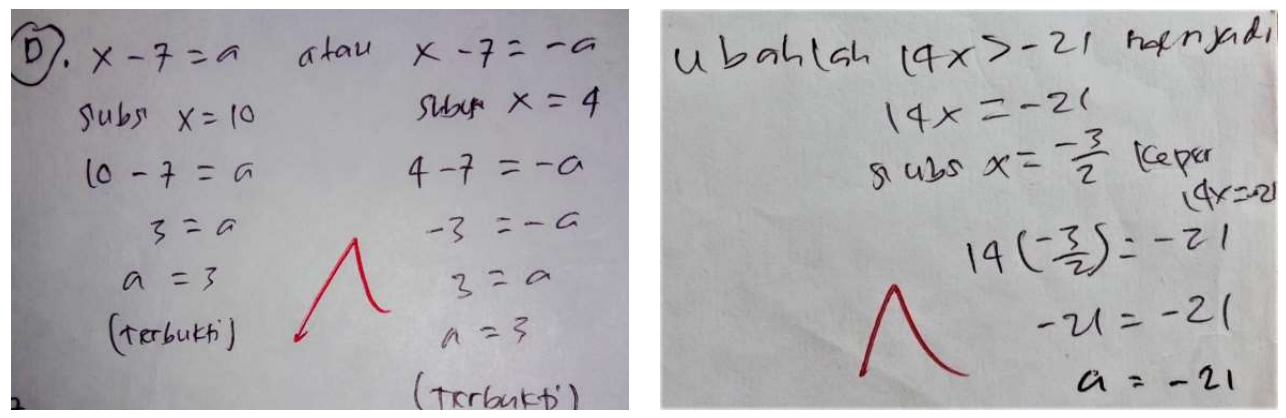

Gambar 4. Tahap memeriksa kembali hasil SV1 soal nomor 1 dan 2

Subjek Visual 2 (SV2)

Tahap Memahami Masalah

Pada tahap memahami masalah, SV2 mampu memahami soal nomor 1 dan soal nomor 2 dengan baik yaitu SV2 mampu mengetahui apa yang diketahui dan ditanyakan dari soal yang diberikan. Hal tersebut terlihat pada gambar 5 berikut.
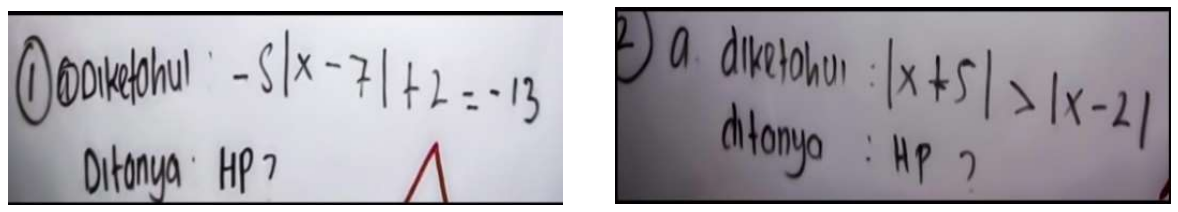

Gambar 5. Tahap memahami masalah SV2 soal nomor 1 dan 2

Tahap Membuat Rencana

SV2 mampu membuat rencana yang mudah dan sederhana untuk menyelesaikan soal nomor 1 dan soal nomor 2. Hal tersebut terlihat pada gambar 6 berikut.
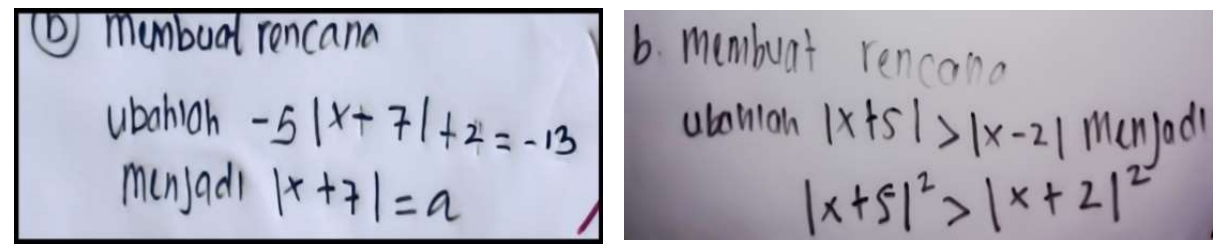

Gambar 6. Tahap membuat rencana SV2 soal nomor 1 dan 2

Tahap Melaksanakan Rencana

Pada tahap melaksanakan rencana SV2 mampu melakukan perhitungan dengan tepat sesuai dengan sifat yang ada pada nilai mutlak. Hal tersebut terlihat pada gambar 7 berikut. 

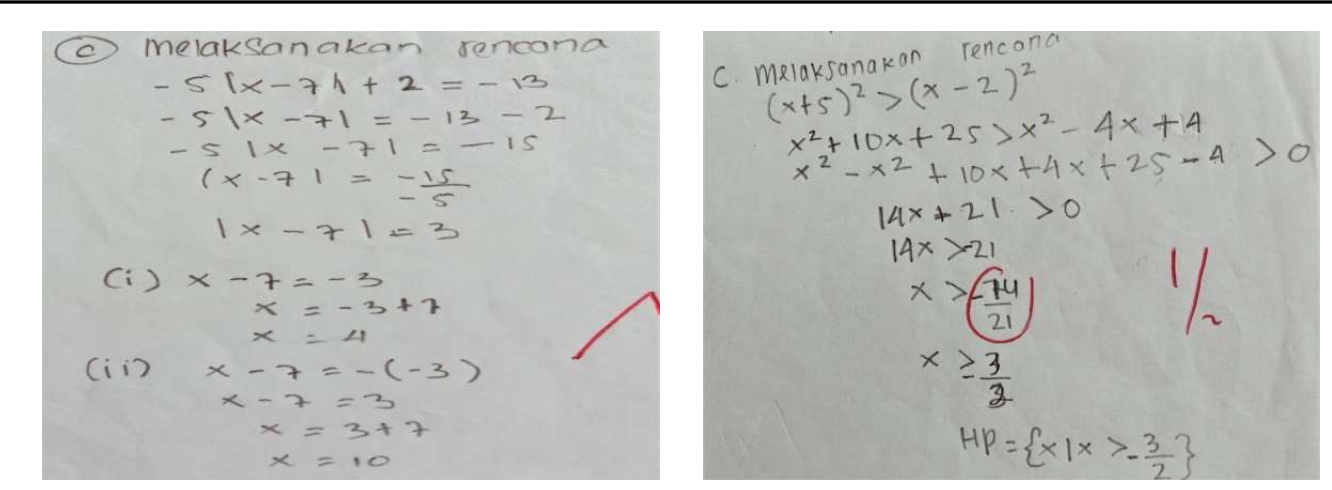

Gambar 7. Tahap melaksanakan rencana SV2 soal nomor 1 dan 2

Tahap Memeriksa Kembali Hasil

Pada tahap memeriksa kembali hasil, SV2 melakukan pengecekan kembali dengan cara memberikan pembuktian jawaban dan membaca kembali pertanyaan. Hal tersebut terlihat pada gambar 8 berikut.
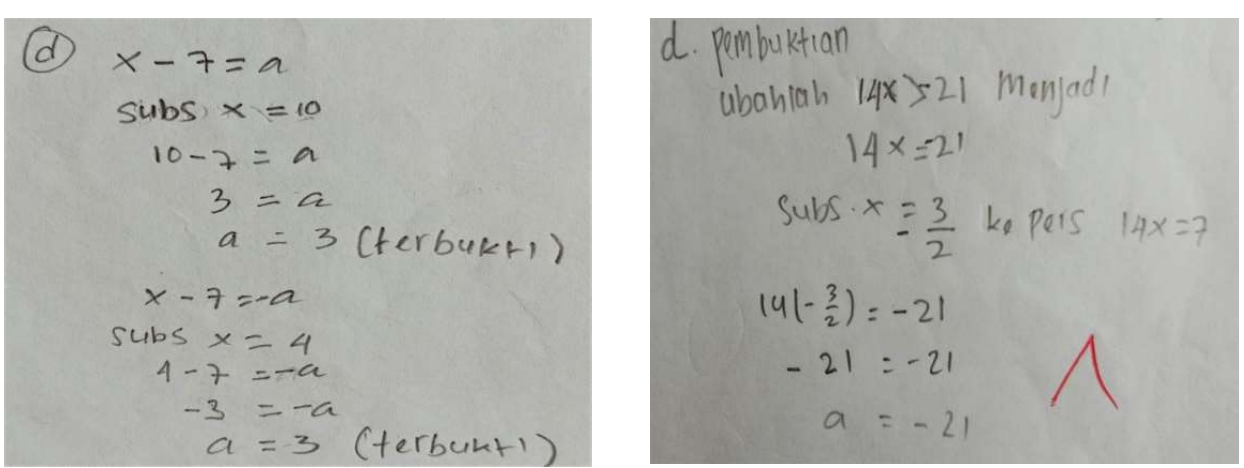

Gambar 8. Tahap memeriksa kembali hasil SV2 soal nomor 1 dan 2

Berdasarkan hasil analisis di atas dapat disimpulkan bahwa siswa visual mampu dalam melaksanakan langkah-langkah pemecahan masalah menurut Polya yaitu memahami masalah, merencanakan atau merancang strategi pemecahan masalah, melaksanakan rencana atau perhitungan dan memeriksa kembali hasil atau solusi. Siswa visual mampu memahami masalah dengan baik yaitu menyebutkan apa yang diketahui dan ditanyakan pada soal yang diberikan, dalam membuat rencana siswa visual mampu membuat rencana dengan mudah dan sederhana, juga mampu melaksanakan rencana dengan melakukan perhitungan yang tepat dan dapat memeriksa kembali penyelesaian dengan cara mengecek jawaban dan membaca kembali pertanyaan.

Proses pemecahan masalah siswa tipe auditorial

Subjek Auditorial 1 (SA1)

Tahap Memahami Masalah

Pada tahap memahami masalah SA1 mampu memahami soal nomor 1 dan soal nomor 2 dengan baik yaitu SA1 mampu mengetahui apa yang diketahui dan ditanyakan dari soal yang diberikan. 

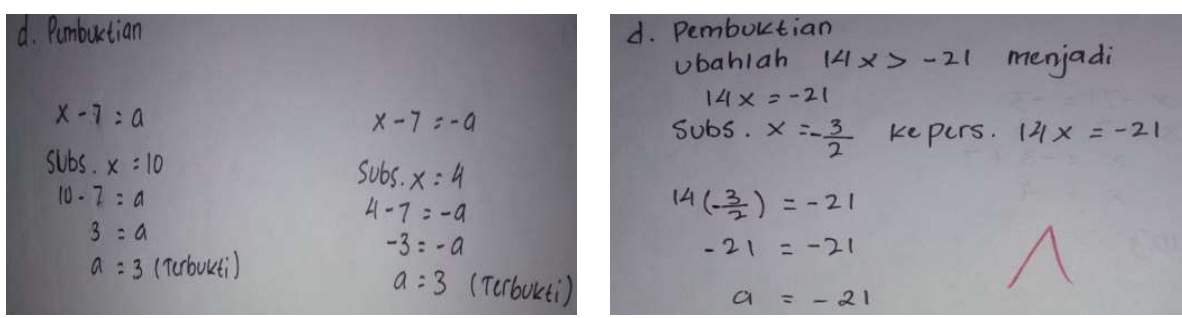

Gambar 12. Tahap memeriksa kembali SA1 soal nomor 1 dan 2

\section{Subjek Auditorial 2 (SA2)}

Tahap Memahami Masalah

Pada tahap memahami masalah SA2 mampu memahami soal nomor 1 dan soal nomor 2 dengan baik yaitu SA2 mampu mengetahui apa yang diketahui dan ditanyakan dari soal yang diberikan. Hal tersebut terlihat pada gambar 13 berikut.

$$
\begin{aligned}
& \text { a). Diketahui: }-5(x-7 \mid+2=-13 \text { a. Diketahui: }|x+5|>|x-2| \\
& \text { Ditanya: HP...? }
\end{aligned}
$$

Gambar 13. Tahap memahami masalah SA2 soal nomor 1 dan 2

Tahap Membuat Rencana

Pada tahap membuat rencana SA2 mampu membuat rencana yang mudah dan sederhana untuk menyelesaikan soal nomor 1 dan soal nomor 2 . Hal tersebut terlihat pada gambar 14 berikut.
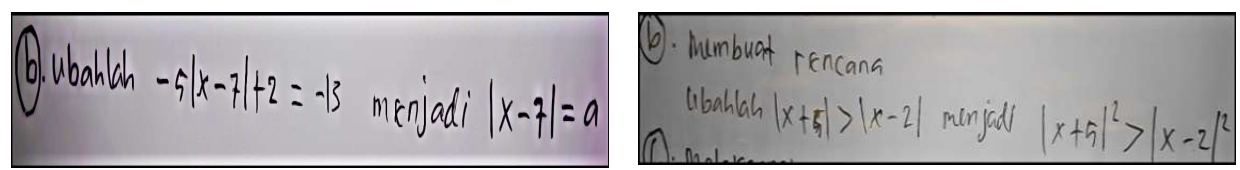

Gambar 14. Tahap membuat rencana SA2 soal nomor 1 dan 2

Tahap Melaksanakan Rencana

Pada tahap melaksanakan rencana SA2 mampu melakukan perhitungan dengan tepat sesuai dengan sifat yang ada pada nilai mutlak. Hal tersebut terlihat pada gambar 15 berikut.
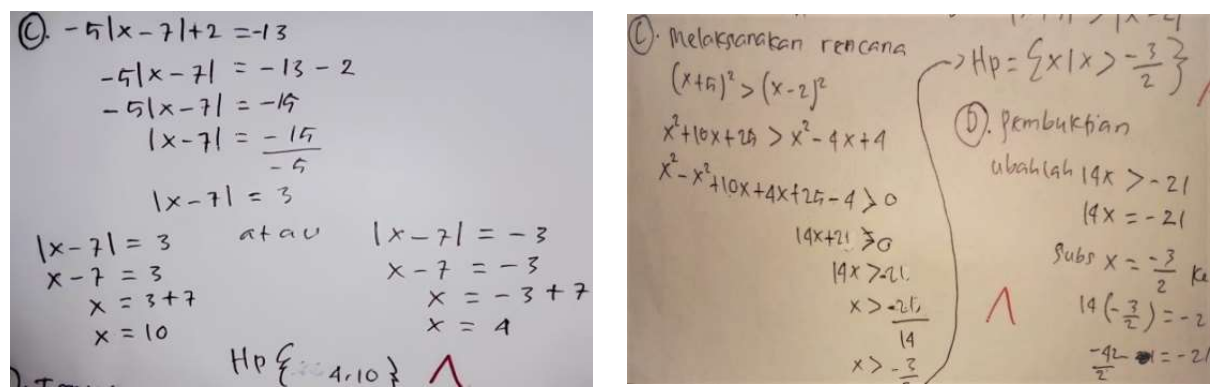

Gambar 15. Tahap melaksanakan rencana SA2 soal nomor 1 dan 2

Tahap Memeriksa Kembali Hasil

(C2020 by Department of Mathematics Education, UMP, Purwokerto, Indonesia p-ISSN2477-409X, e-ISSN: 2549-9084 and website: http://jurnal nasional.ump.ac.id/index.php/alphamath/ 
Pada tahap memeriksa kembali hasil SA2 melakukan pengecekan kembali dengan cara memberikan pembuktian jawaban dan membaca kembali pertanyaan. Hal tersebut terlihat pada gambar 16 berikut.
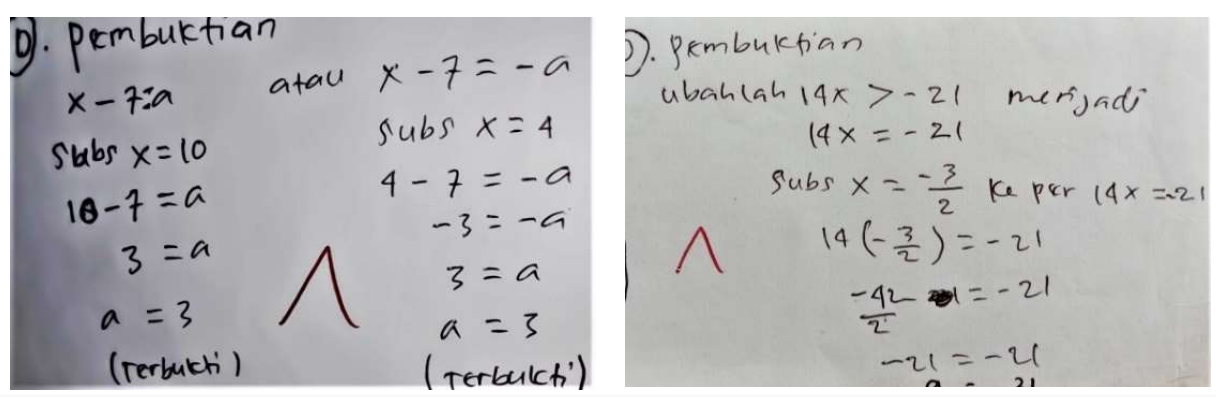

Gambar 16. Tahap memeriksa kembali hasil SA2 soal nomor 1 dan 2

Berdasarkan hasil analisis di atas dapat disimpulkan bahwa siswa auditorial mampu dalam melaksanakan langkah-langkah pemecahan masalah menurut Polya yaitu memahami masalah, merencanakan atau merancang strategi pemecahan masalah, melaksanakan rencana (perhitungan) dan memeriksa kembali hasil atau solusi. Pada tahap memahami masalah siswa auditorial mampu memahami masalah dengan baik yaitu menuliskan apa yang diketahui dan ditanyakan dari soal yang diberikan, dalam membuat rencana siswa auditorial mampu membuat rencana dengan mudah dan sederhana, juga mampu melaksanakan rencana dengan melakukan perhitungan yang tepat dan juga dapat memeriksa kembali penyelesaian dengan cara mengecek jawaban dan membaca kembali pertanyaan.

\section{Proses pemecahan masalah siswa tipe kinestetik}

\section{Subjek Kinestetik 1 (SK1)}

Tahap Memahami Masalah

Pada tahap memahami masalah SK1 mampu memahami soal nomor 1 dan soal nomor 2 dengan baik yaitu SK1 mampu mengetahui apa yang diketahui dan ditanyakan dari soal yang diberikan. Hal tersebut terlihat pada gambar 17 berikut.
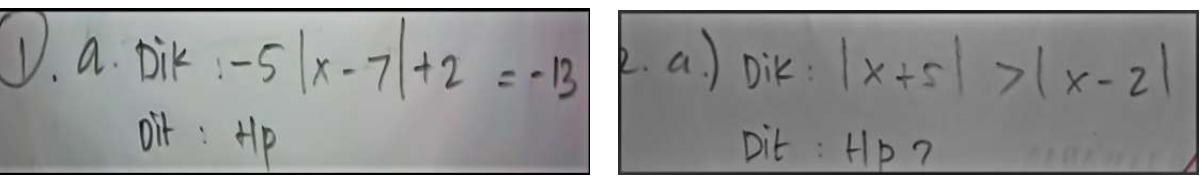

Gambar 17. Tahap memahami masalah SK1 soal nomor 1 dan 2

Tahap Membuat Rencana

Pada tahap membuat rencana SK1 mampu membuat rencana yang mudah dan sederhana untuk menyelesaikan soal nomor 1 dan soal nomor 2. Hal tersebut terlihat pada gambar 18 berikut.
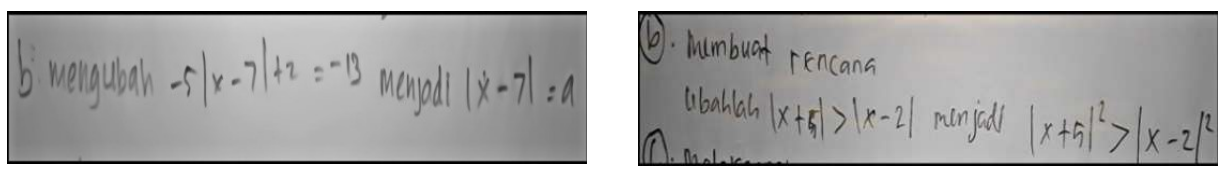

Gambar 18. Tahap membuat rencana SK1 soal nomor 1 dan 2 
Tahap Melaksanakan Rencana

Pada tahap melaksanakan rencana SK1 mampu melakukan perhitungan dengan tepat sesuai dengan sifat yang ada pada nilai mutlak. Hal tersebut terlihat pada gambar 19 berikut.
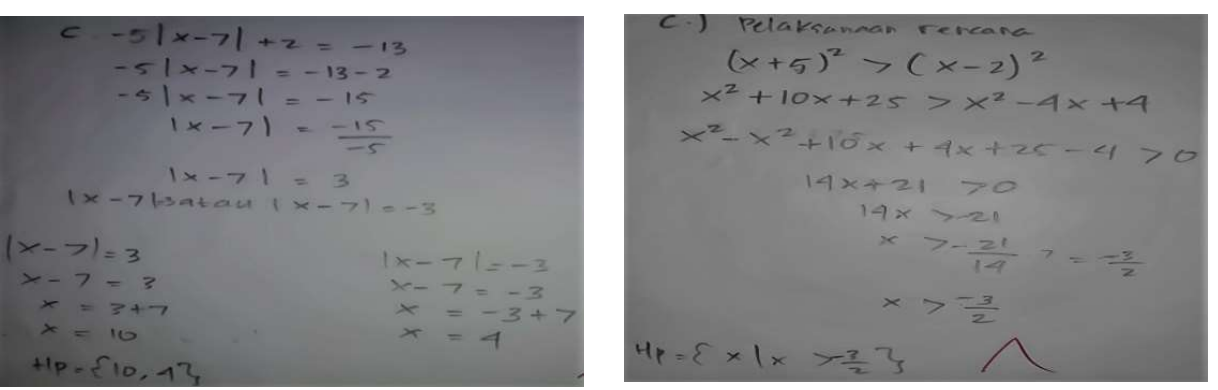

Gambar 19. Tahap melaksanakan rencana SK1 soal nomor 1 dan 2

Tahap Memeriksa Kembali Hasil

Pada tahap memeriksa kembali hasil SK1 juga melakukan pengecekan kembali dengan cara memberikan pembuktian jawaban dan membaca kembali pertanyaan. Hal tersebut terlihat pada gambar 20 berikut.
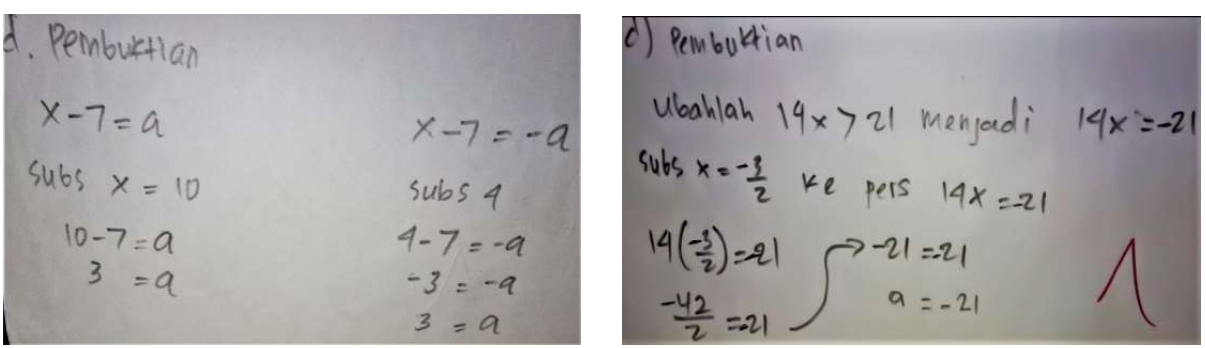

Gambar 20. Tahap memeriksa kembali hasil SK1 soal nomor 1 dan 2

\section{Subjek Kinestetik 2 (SK2)}

Tahap Memahami Masalah

Pada tahap memahami masalah SK2 mampu memahami soal nomor 1 dan soal nomor 2 dengan baik yaitu SK2 mampu mengetahui apa yang diketahui dan ditanyakan dari soal yang diberikan. Hal tersebut terlihat pada gambar 21 berikut.
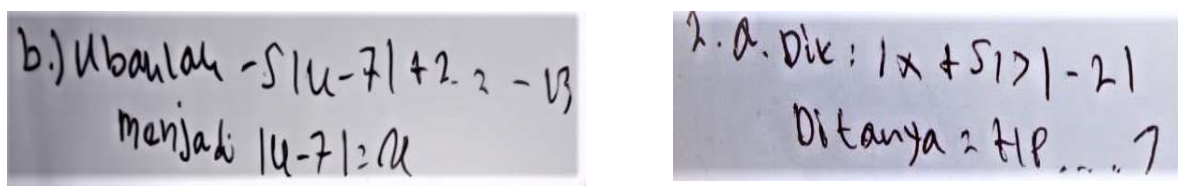

Gambar 21. Tahap memahami masalah SK2 soal nomor 1 dan 2

Tahap Membuat Rencana

Pada tahap membuat rencana SK2 belum mampu membuat rencana penyelesaian masalah dengan benar pada soal nomor 1 tetapi SK2 memahami maksud soal yang diberikan. Hal tersebut terlihat pada gambar 22 berikut. 


$$
\begin{aligned}
& \text { b.) Ubaulau }-5|u-7|+2.2-13 \\
& \text { monjadi }|u-7|=2 u
\end{aligned}
$$

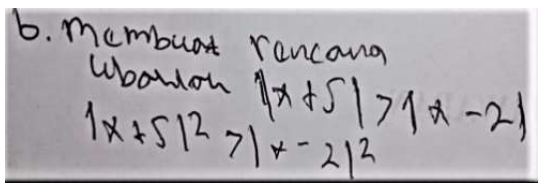

Gambar 22. Tahap membuat rencana SK2 soal nomor 1 dan 2

Tahap Melaksanakan Rencana

Pada tahap melaksanakn rencana SK2 melakukan perhitungan dengan tepat sesuai dengan sifat yang ada pada nilai mutlak. Hal tersebut terlihat pada gambar 23 berikut.
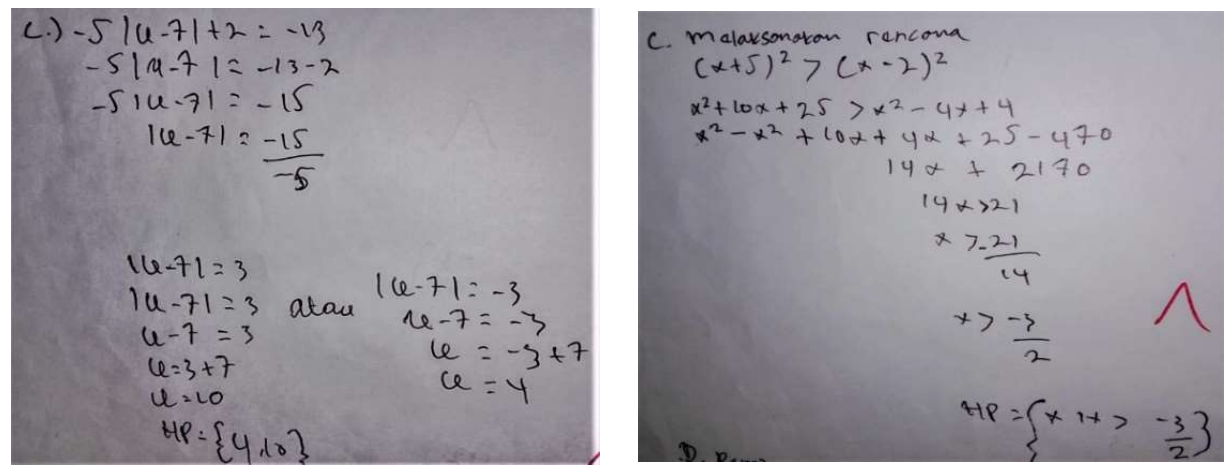

Gambar 23. Tahap melaksanakan rencana SK2 soal nomor 1 dan 2

Tahap Memeriksa Kembali Hasil

Pada tahap memeriksa kembali hasil SK2 melakukan pengecekan kembali dengan cara memberikan pembuktian jawaban dan membaca kembali petanyaan. Hal tersebut terlihat pada gambar 24 berikut.
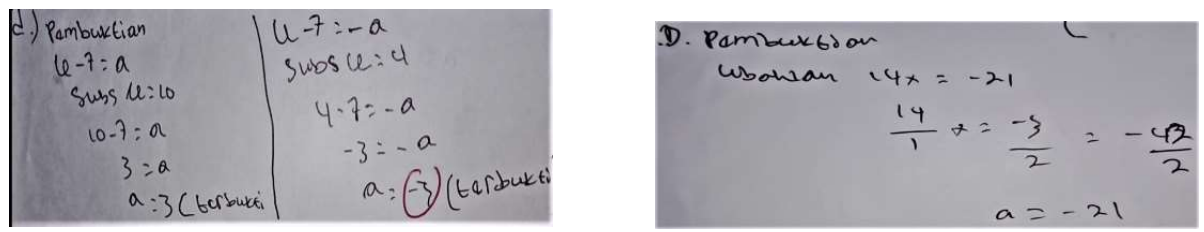

Gambar 24. Tahap memeriksa kembali hasil SK2 soal nomor 1 dan 2

Berdasarkan hasil analisis di atas dapat disimpulkan subjek kinestetik mampu dalam memahami masalah dengan baik yaitu mampu menuliskan yang diketahui dan ditanyakan pada soal yang diberikan, namun dalam membuat rencana siswa kinestetik belum mampu membuat rencana penyelesaian yang tepat pada materi persamaan nilai mutlak linear satu variabel sehingga terkendala dalam melakukan perhitungan, dan siswa kinestetik dapat memeriksa kembali penyelesaian dengan cara mengecek jawaban dan membaca kembali pertanyaan.

Dari ketiga gaya belajar tersebut dapat disimpulkan bahwa siswa dengan gaya belajar visual mampu memahami masalah dengan baik, membuat rencana yang mudah dan sederhana sehingga dalam melaksanakan rencana mampu melakukan perhitungan dengan tepat, dan dalam 
memeriksa kembali hasil siswa visual mengecek perhitungan dan membaca kembali pertanyaan. Siswa gaya belajar auditorial secara umum memahami masalah dengan baik, pada tahap membuat rencana secara umum sudah merencanakan penyelesaian masalah dengan baik, dalam melaksanakan rencana mampu melakukan perhitungan dengan tepat dan dalam memeriksa kembali hasil dengan mengecek perhitungan dan membaca kembali pertanyaan. Siswa dengan gaya belajar kinestetik secara umum memahami masalah dengan baik, tetapi pada tahap membuat rencana kurang baik karena kurang mampu membuat rumus dalam menyelesaikan soal yang diberikan sehingga belum mampu menyelesaikan masalah dan melakukan perhitungan. Dalam memeriksa kembali hasil dengan mengecek perhitungan dan membaca kembali pertanyaan. Oleh karena itu untuk siswa dengan gaya belajar visual dan auditorial mempunyai kemampuan pemecahan masalah yang sama baiknya sedangkan gaya belajar kinestetik belum mempunyai kemampuan pemecahan masalah yang baik karena belum dapat membuat rencana dan menyelesaikan masalah. Hasil penelitian ini sejalan dengan penelitian Umrana dkk (2019) dengan hasil penelitian sebagai berikut: kemampuan pemecahan masalah matematis siswa yang bergaya belajar visual menurut pentahapan Polya mampu dengan baik dalam memahami masalah, merencanakan pemecahan masalah, melaksanakan rencana pemecahan masalah dan memeriksa kembali hasil jawaban, 2) Kemampuan pemecahan masalah matematis siswa yang bergaya belajar auditori menurut pentahapan Polya mampu dengan baik dalam memahami masalah, membuat rencana pemecahan masalah, melaksanakan rencana pemecahan masalah dan memeriksa kembali hasil pemecahan masalah, 3) Kemampuan pemecahan masalah matematis siswa yang bergaya belajar kinestetik menurut pentahapan Polya mampu dengan baik dalam memahami masalah, dan membuat rencana pemecahan masalah, kurang mampu melaksanakan rencana pemecahan masalah pada indikator kemampuan melakukan perhitungan sesuai dengan rumus yang diguanaka utamanya pada perkalian dan pembagian, serta kurang mampu memeriksa kembali hasil pemecahan masalah.

\section{Simpulan}

Berdasarkan hasil analisis data dan pembahasan diperoleh simpulan sebagai berikut: Siswa dengan gaya belajar visual mampu memahami masalah dengan baik, membuat rencana yang mudah dan sederhana sehingga dalam melaksanakan rencana mampu melakukan perhitungan dengan tepat, dan dalam memeriksa kembali hasil siswa visual mengecek perhitungan dan membaca kembali pertanyaan. Siswa gaya belajar auditorial secara umum memahami masalah dengan baik, pada tahap membuat rencana secara umum sudah merencanakan penyelesaian masalah dengan baik, dalam melaksanakan rencana mampu melakukan perhitungan dengan tepat dan dalam memeriksa kembali hasil dengan mengecek perhitungan dan membaca kembali pertanyaan. Siswa dengan gaya belajar kinestetik secara umum memahami masalah dengan baik, tetapi pada tahap membuat rencana kurang baik karena kurang mampu membuat rumus dalam menyelesaikan soal yang diberikan sehingga belum mampu menyelesaikan masalah dan melakukan perhitungan. Dalam memeriksa kembali hasil dengan mengecek perhitungan dan membaca kembali pertanyaan.

Berdasarkan simpulan di atas, saran dari penelitian ini adalah sebagai berikut: 1) Hendaknya siswa mengerjakan soal dengan tahap-tahapan pemecahan masalah yang benar, memperinci langkah-langkah dan tidak tergesa-gesa sehingga hasil jawaban lebih akurat. 2) Guru perlu membudayakan pengajaran mengenai pemecahan masalah siswa dengan melibatkan banyak gaya belajar secara bersamaan. 3) Guru harus mengetahui klasifikasi gaya belajar yang dimiliki oleh peserta didiknya supaya proses belajar mengajar dapat berjalan dengan baik. 
ANGGELIA WILLIA, PRADIPTA ANNURWANDA, RIZKI NURHANA FRIANTINI

Proses Pemecahan Masalah Matematika Ditinjau dari Gaya Belajar Siswa

\section{Daftar Pustaka}

Agustina, R. 2014. Penyelesaian masalah matematika pada tipe kepribadian phlegmatis. AksiomaJurnal Pendidikan Matematika FKIP Universitas Muhammadiyah Metro. Vol 3 No. 2 ISSN 2442-5419. 16-22

Arikunto, S. 2010. Prosedur Penelitian Suatu Pendekatan Praktik. Jakarta: PT Rineka Cipta.

Deporter, B. \& Hernacki, M. 2012. Quantum Learning. Bandung: Kaifa.

Friantini, R. N. \& Winata, R. 2018. Eksperimentasi Metode STAD dan TGT Terhadap Prestasi Belajar Matematika Ditinjau dari Gaya Belajar. EduSains: Jurnal Pendidikan Sains \& Matematika. Vol. 6, No. 2.

Hidayah, S. 2016. Analisis Kesalahan Siswa Dalam Menyelesaikan Soal Cerita SPLDV Berdasarkan Langkah Penyelesaian Polya. Prosiding Seminar Nasional Pendidikan Matematika. Vol. 1. ISSN: 2528-259X. 182-190

Nurfatanah., Rusmono \& Nurjannah. 2018. Kemampuan Pemecahan Masalah Matematika Siswa Sekolah Dasar. Prosiding Seminar Dan Diskusi Nasional Pendidikan Dasar. ISSN: 2528-5564. 546-551

Sugiyono. 2011. Metode Penelitian Kuantitatif, Kualitatif dan R\&D. Bandung: Alfabeta

Sugiyono. 2017. Metode Penelitian Kuantitatif, Kualitatif dan R\&D. Bandung: Alfabeta.

Ulvah, S., Afriansyah, E.A. 2016.Kemampuan Pemecahan Masalah Matematis Siswa Ditinjau Melalui Model Pembelajaran SAVI Dan Konvensional. Jurnal Riset Pendidikan. Vol. 2, No. 2. ISSN: 2460-1470. 142-153

Umrana, U., Cahyono, E., \& Sudia, M. 2019. Analisis Kemampuan Pemecahan Masalah Matematis Ditinjau Dari Gaya Belajar Siswa. Jurnal Pembelajaran Berpikir Matematika. Vol. 4, No. 1

Winata, R \& Friantini, R.N. 2018a. Proses Pemecahan Masalah Mahasiswa Pendidikan Matematika STKIP Pamane Talino. FIBONACCI : Jurnal Pendidikan Matematika dan Matematika. Vol. 4. No. 1. ISSN: 2460 - 7797. 87-96

Winata, R \& Friantini, R.N. 2018b. Analisis Kesalahan Siswa Kelas VII MTs Negeri 1 Landak pada Pemecahan Masalah Operasi Aljabar. Al-Khwarizmi: Jurnal Pendidikan Matematika dan Ilmu Pengetahuan Alam. Vol. 6. No. 2. Hal. 89-108.

Winata, R., Friantini, R. N., Annurwanda, P., Annur, M. F., Permata, J. I. 2020. The Arguments of Mathematics Education Studentsto Solve Proof Problems. AIP Coference Proceedings 2268, 030008 (2020). 